\title{
AN ANALYSIS OF MADURESE DIALECT IN THE ENGLISH CONVERSATION BY THE MEMBERS OF BATA-BATA ENGLISH CENTRE (BBEC)
}

\author{
Imroatul Mufidah' \\ ${ }^{1}$ English Teaching Learning Program, Tarbiyah Faculty, Institut Agama Islam Negeri Madura, \\ Indonesia \\ (z.imroatulmufidah@gmail.com) \\ Eva Nikmatul Rabbianty ${ }^{2}$ \\ ${ }^{2}$ English Teaching Learning Program, Tarbiyah Faculty, Institut Agama Islam Negeri Madura, \\ Indonesia \\ (eva@iainmadura.ac.id)
}

\begin{abstract}
The concept of world Englishes refers to English as a global language that means communication in numerous dialects and the movement towards an international standard for English. Varieties of English are used in various sociolinguistic contexts in different parts of the world, also in Indonesia. Since English plays as a foreign language, sometimes Indonesians still use their dialect. This study was mainly purposed to describe Madurese dialect in the English conversation made by Bata-Bata English Centre (BBEC). Mainly, this research is aimed to (1) Describe the patterns of Madurese dialect in English conversation by the members of the Bata-Bata English Centre (BBEC). (2) Know the factors that affect the pattern of Madurese dialect in the English conversation by the Bata-Bata English Centre (BBEC). This research belongs to qualitative research which investigates the group of BBEC about Madurese dialect in their English conversation. The researcher observed the students' learning process, interviewed them and took notes, recordings, and pictures. The study results were that the researcher found the patterns of Madurese dialect occur in the English conversation in three features: pronunciation which caused sound changing, a grammatical pattern that caused incorrect grammar; and inappropriate vocabulary. Second, the researcher found that three factors affected how their dialect in the English conversation. The first is lack of speech, Madurese language influences second, and the last factor is never listening to native English speakers. Madurese language that plays as their mother tongue influences their dialect in the English conversation.
\end{abstract}

Keywords: Dialect; Dialect Pattern; English Conversation

First Received:

(September 11, 2021)
Final Proof Received:

(September 27, 2021)

\section{INTRODUCTION}

A language is a tool for communication that all people need. As social creatures, human beings cannot live alone, and they need each other. They live in society, and they are grouped. Therefore, they need language as a tool to communicate in making interaction with each other. Indonesia is expanding circle country (Nordquist, 2019). Since it is not an inner or outer circle country, English plays as a foreign language. It means that English is not the first or even second language, that is why some people only use English 
Imroatul Mufidah \& Eva Nikmatul Rabbianty, Madurese Dialect in the English ...

in some critical moment or some needs, for example, most of the students of Indonesia use English only in their English lesson in school. Since it is rarely used as a medium of communication, students may find many difficulties using English. Because of that, sometimes, when they talk using English, they still use their dialect.

Syahreni Siregar states in her research that the influence of dialect on the student's pronunciation in speaking ability that Non-Native speakers of English tend to bring over the intonation and phonemic inventory from their mother tongue into their English speech (Siregar, 2017). It also happens to members of Bata-Bata English Centre (BBEC). BBEC as an English short course facilitates English ability to their members which most of them are Madurese. They still use their own dialect in English conversations. It can be from pronunciation, vocabulary, or even grammatical patterns. For example, they always add sound [e] before the word "no," "still," and "right." They also add sound [i] before word "yes" (Hidayati \& Thayyibah, 2020). Then, in grammatical patterns, they always forget to put (to be) of their utterance because, in Madurese language, they do not need to use to be. It also happens in their vocabulary that they use inappropriate vocabulary. Because of that, the researcher intends to research an analysis of Madurese dialect in their English conversation.

We understand that every group of people has their own language that is different from others. Although there are languages that are used by more than one group of the society, it does not indicate that the language has the same pattern, vocabulary, and pronunciation (Holmes, 2013). There are many different patterns of language use which are called language variation. It closely tightens to the culture and society. Hudson defines a variety of language in Ronald Wardhaugh's book as "a set of linguistic items with similar distribution," a definition that allows us to say that all of the following are varieties: Canadian English, London English, the English of football commentaries, and so on (Wardhaugh, 2006).

Many researchers in a diverse area held the investigating of the dialect. Isiaka stated that the influence of speaker attitude, age-group, and interactional frequency are composite and synchronously correlated with the degrees of convergence to the new dialect (Isiaka, 2021). Regional dialect takes a crucial role in the English conversation as, like Clopper \& Smiljanic revealed significant effects of regional dialect on the distributions of pauses, pitch accents, and phrasal-boundary tone combinations (Clopper \& Smilijanic, 2011). Then, the study of Azror stated that regional, in the case of Madurese, plays a role in the patterns of students' English (Azror, 2016). Also, Siregar, in her study which only focuses on pronunciation (Siregar, 2017). The current study was designed to explore all of those three patterns of dialect based on Holmes, that dialects are linguistic varieties which are distinguishable by their vocabulary, grammar, and pronunciation (Holmes, 2013), every person will have their own dialect although talk the same language; English and we can know about it by investigating their vocabulary, grammar and also pronunciation. 
Based on the phenomena which happened at Bata-Bata English Centre (BBEC), the researcher is interested in executing research about an analysis of Madurese dialect in the English conversation by the members of Bata-Bata English Centre (BBEC). The main goals of this study are to answer the question of what are the patterns of Madurese dialect in the English conversation by the members of BBEC? And what are the factors that affect Madurese dialect in the English conversation by the member of BBEC?

\section{LITERATURE REVIEW}

\section{Sociolinguistics}

Sociolinguistics talks about society and language. Sociolinguistics is a study that concerns the language that is used in society. It is in line with the statement of Janet Holmes in his book that sociolinguistics study is the relationship between language and society. They are interested in explaining why we speak differentially in a different social context, and they are concerned with identifying the social functions of language and how it is used to convey social meaning (Holmes, 2013). While Gumperz has observed that sociolinguistics is an attempt to find correlations between social structure and linguistic structure and to observe any changes. Besides that, Chambers is even more direct: 'Sociolinguistics is the study of the social uses of language, and the most productive studies in the four decades of sociolinguistic research have emanated from determining the social evaluation of linguistic variants (Wardhaugh, 2006). According to sociolinguistics, a language is a code. The wide varieties within the code are; Dialects, Registers, Idiolects, Dioglossia, Pidgins, Creole (R Umagandhi \& R Sindhuja, 2017).

\section{Dialect}

A local, chronological or social diversity within a lone language is a dialect; it differs in pronunciation, grammar, and vocabulary from the standard language, which is in itself a socially favored dialect.

\section{Definition of Dialect}

A dialect is a form of a language used in part of a country (Eastwood, 2008). Besides that, according to Ronald's book, Haugen (1966a) has pointed out that language and dialect are ambiguous terms. Ordinary people use these terms quite freely in speech; for them, a dialect is almost certainly no more than a local non-prestigious (therefore powerless) variety of a real language. In contrast, scholars often experience considerable difficulty in deciding whether one term should be used rather than the other in certain situations (Wardhaugh, 2006). Dialect refers to a variation of a language that is characteristic of the users of that language. Dialects are different ways of saying the same thing; they reflect the social structure, e.g., class, gender, and origin (Salano-Flores, 2006). A dialect is any variety of language spoken by a group of people characterized by 
Imroatul Mufidah \& Eva Nikmatul Rabbianty, Madurese Dialect in the English ...

systematic differences from other types of the same language in terms of structural or lexical features (Jannedy et al., 1994).

\section{Types of Dialect}

There are two types of dialect. The first is regional dialect. There are differences in the varieties spoken in different regions. It can be vocabulary, pronunciation, or even grammatical patterns. For example, South Africans use the term robot for British traffic lights. British wellies (Wellington boots) are New Zealand gummies (gumboots), while the word togs refer to very different types of clothes in different places (Holmes, 2013).

The second is a social dialect. The term dialect can also be used to describe differences in speech associated with various social groups or classes. Social dialect research in many different countries has revealed a consistent relationship between social class and language patterns. People from different social classes speak differently. The term is social class is used here as a shorthand term for differences between people, which are associated with differences in social prestige, wealth, and education (Holmes, 2013). For example, bank managers do not talk like office cleaners.

\section{Patterns of Dialect}

Based on Janet Holmes, dialects are linguistic varieties distinguishable by their vocabulary, grammar, and pronunciation; the speech of people from different social (Holmes, 2013). In the study entitled English Speaking Dialect Used by Madurese Students of SMPN 1 Klampis in Bangkalan, Madura, Azror stated that the pattern of English speaking dialect used by the students from Madura produced some errors in phonological feature (adding e and i), grammatical pattern (subject omitting, object omitting, object changing, verb omitting, verb changing, auxiliary verb omitting, auxiliary verb changing, preposition omitting, preposition changing), and also vocabulary variation (Azror, 2016).

\section{Vocabulary}

The most obvious differences - in vocabulary - are in many ways the least illuminating from a sociolinguistic point of view, though they clearly capture the public imagination. In the 1950s in England, many pairs of words were identified which, it was claimed, distinguished the speech of upper-class English people ('U speakers') from the rest ('non-U speakers'). U speakers used sitting room rather than lounge (non-U) and referred to the lavatory rather than the (non-U) toilet. There are vocabulary differences in the varieties spoken in different regions. Australians talk of sole parents, for example. While people in England call them single parents and New Zealanders call them solo parents (Holmes, 2013). 


\section{Pronunciation}

The differences of dialects could be placed in the pronunciation. Speakers of different English dialects pronounce some words differently from those of other speakers. However, native-like pronunciation may be a goal for particular learners (Kenworthy, 1987).

Fasold and Connor-Linton stated that dialects differ from one another not only in terms of lexical items but also in terms of their pronunciation systems or phonology. It means that dialects have differences in lexical, pronunciation, or phonology (Fasold \& Connor-Linton, 2006). For example, in some English dialects such as /h/ regularly dropped from the most word in which it is pronounced in American, such as a house, pronounce /aws/, and hero, pronounced /iro/ (Fromkin et al., 2003).

\section{Grammatical Patterns}

Pronunciation and vocabulary differences are probably the most common differences between different dialects of English, but there are grammatical differences too. For example, she walks (standard), and she walks (vernacular). Holmes stated that there is a sharp distinction between the middle-class groups and the lower-class groups. Sociolinguists describe this pattern as sharp stratification. People are often more aware of social stigma related to vernacular grammatical forms, which is reflected in the lower incidence of vernacular forms among middle-class speakers in particular. Note that this pattern is found both in a variety of US English spoken in Detroit and in a variety of British English spoken in Norwich (Holmes, 2013).

There are some regularized forms of grammatical differences: 1) Absence of inflectional morphemes, 2) third-person singular -s absence; e.g. He go (African American English), 3) Possessive -s absence; e.g., the man hat (African American English), 4) Plural s absence; e.g., five-mile (Southern vernacular dialects), 5) Addition of inflectional endings, 6) Possessive pronouns; e.g., mines (African American English; selected vernacular dialects); hisn (southern Appalachian dialects), 7) More transparent forms, 8) Doublemarked comparatives and superlatives; e.g. most beautifulest (most vernacular dialects), 9) Marking of second-person plural forms; e.g. y'all (Southern dialects); you'ns (southern Appalachian dialects, Pittsburgh dialect); youse/youse guys (Northern dialects, especially Northeastern), 10) Retention of a- prefix; e.g. a-huntin' and a-fishin' (Appalachian English)(Wolfram \& Friday, 1997).

\section{Factors Affecting Dialect}

Many different factors affect a dialect. One of the studies which discussed it held by Baker, Eddington, and Nay which title is "Dialect Identification: The Effect of Region of Origin and Amount of Experience." This study provides evidence that region of origin and amount of experience are significant factors in dialect identification (Baker et al., 2007). 
Imroatul Mufidah \& Eva Nikmatul Rabbianty, Madurese Dialect in the English ...

While based on Janet holmes, there are two factors, Regional and social. There are many such stories - some no doubt apocryphal - of mistakes based on regional accent differences. To British ears, a New Zealander's dad sounds like an English person's dead, bad sounds like bed, and six sounds like sucks (Holmes, 2013). Ethnic also influences how people speak English differently. The differences that English speakers throughout the world notice when they meet English speakers from other nations are similar to those noted by speakers of other languages, too (Holmes, 2013). The second is social. The term social class is used here as a shorthand term for differences between people, which are associated with differences in social prestige, wealth, and education (Holmes, 2013).

Beard in Mantiri stated that languages change for various reasons such as political pressures, technological development, and social, cultural, and moral factors. Below are examples of causes that lead to change in the English language.

a. Political factor- which is caused by foreign invasion, migration and colonization.

b. Social factor means foreign influences from Latin, French, American, Australian, Indian, and others. The unique way that individuals also speak fuels language change. People's vocabulary and phrases depend upon the place, age, gender, education level, and social status.

c. Cultural factor- This means the exposure of one language group to another via television, radio, films, music, magazines, and fashion.

d. Technological factor means rapid advances in information technology, industries, products, and economy require new words that drive language change.

e. Moral factor- which is about recent developments in anti-racism and environmentalism (Mantiri, 2010).

\section{METHOD}

The researcher used a qualitative research approach. The object of this research was only one group of Bata-Bata English Centre (BBEC) which consisted of ten persons. The researcher used observation, interviews, and documentation to collect the data. There were some steps of research in conducting this research. The first was interviewing the members of the Bata-Bata English Center (BBEC). The second was observing the English conversations of the members of BBEC in front of the room and recording their conversations. The third was listening to the utterance by playing and pausing the recording of their conversation to analyze Madurese language used by members of BBEC. The fourth was sorting all dialects in their conversation and then making a table to put all their utterance data. While the data analysis consisted of three steps; first, the researcher resumed the data from the subject of the research. Second, before displaying by narrative text, the researcher grouped into several classifications on a table. Then, the last was making a conclusion and verification. 


\section{RESULTS AND DISCUSSION}

\section{Results}

The researcher wants to describe the data found during the research process at Bata-Bata English Centre (BBEC) members.

\section{Patterns of Madurese Dialect by the Members of BBEC}

Most of the members of Bata-Bata English Centre (BBEC) are Madurese. Madura people have their own language, which is used in daily conversation, namely Madurese language. So, every day they use Madurese language to communicate and to interact with each other. Because of that, when they talk using English, they will not be able to avoid their Madurese dialect because English is their foreign language, while Madurese is their mother tongue. As like what has been stated that English is reflected in every language variety's pronunciation, vocabulary, grammatical constructions, and syntax(Shams, 2018).

Concerning the analysis of Madurese dialect, which happens in the English conversation by the members of BBEC, the researcher focuses on analyzing the pattern of pronunciation, grammatical pattern, and vocabulary variation that differ from the standard one.

Table 1.

Students Dialect Pattern

\begin{tabular}{|c|c|c|}
\hline \multicolumn{2}{|l|}{ Pattern } & Note \\
\hline \multirow[t]{13}{*}{ Vocabulary } & \multirow{13}{*}{$\begin{array}{l}\text { Inappropriate } \\
\text { Vocabulary }\end{array}$} & She gives me advise (Data 1, line 11) \\
\hline & & She is fine and beautiful (Data 1 , line 12 ) \\
\hline & & you can see alone (Data 1 , line 12 ) \\
\hline & & People from another country make one contest \\
\hline & & The translator give me understand (Data 6, line 56) \\
\hline & & The tittle is Miss Farihah (Data 6, line 59) \\
\hline & & $\begin{array}{l}\text { Do you ever journey with your relative? (Data } 8 \text {, line } \\
\text { 10) }\end{array}$ \\
\hline & & What's your parent work? (Data 8, line 17) \\
\hline & & I don't know work (Data 8, line 18) \\
\hline & & I don't know work my parent (Data 8, line 19) \\
\hline & & My mother always angry to me (Data 8, line 21) \\
\hline & & My parent always angry to me (Data 8, line 23) \\
\hline & & What your motivator? (Data 8 , line 32 ) \\
\hline
\end{tabular}


Imroatul Mufidah \& Eva Nikmatul Rabbianty, Madurese Dialect in the English ...

\begin{tabular}{|c|c|c|}
\hline & & \\
\hline & & Are you just pupil? (Data 10, line 10) \\
\hline & & Yes, I am just pupil (Data 10, line 10) \\
\hline & & How are you today? (Data 12, line 5) \\
\hline & & $\begin{array}{l}\text { I feel this night I am very beautiful and sweet (Data } \\
12 \text {, line 11) }\end{array}$ \\
\hline & & I have two parent (Data 12 , line 34 ) \\
\hline & & Can I story? (Data 12, line 48) \\
\hline & & My father don't dear me (Data 12, line 53) \\
\hline & & $\begin{array}{l}\text { And now, my mother three, my three mother is } \\
\text { pregnant (Data 12, line 57) }\end{array}$ \\
\hline & & I have is Laila, Linda, and Nova (Data 13 , line 40 ) \\
\hline & & Oh you don't know swimming (Data 13 , line 45 ) \\
\hline & & I look gamers make people happy (data 13 , line48) \\
\hline & & Could you have sister? (Data 14, line 6) \\
\hline & & What child from your parent? (data 14 , line 10 ) \\
\hline & & $\begin{array}{l}\text { Before you choose English language in IAIN (Data } \\
15 \text {, line 17) }\end{array}$ \\
\hline & & $\begin{array}{l}\text { I am afraid don't answer your question (data } 15 \text {, line } \\
\text { 35) }\end{array}$ \\
\hline & & Study (Data 16, line 11) \\
\hline & & You always travelling in Korea (Data 16, line 50) \\
\hline & & Do you ever travelling to Korea (Data 16 , line 51 ) \\
\hline & & But, I don't never look you (Data 16, line 53) \\
\hline & & $\begin{array}{l}\text { if I speak English, little-little I know in vocabulary } \\
\text { and grammatical (Data 18, point 8) }\end{array}$ \\
\hline & & $\begin{array}{l}\text { I think difficult if I speak English (Data 18, point 8) } \\
\text { interview }\end{array}$ \\
\hline Grammatical & Subject Omitting & Only watch in the television (Data 2 , line 9) \\
\hline & & Go to the zoo with my family (Data 3 , line 4 ) \\
\hline & & $\begin{array}{l}\text { So, give her knowledge to other people (Data 6, line } \\
40 \text { ) }\end{array}$ \\
\hline & & I think very love her (Data 8, line 35) \\
\hline & & The same with me (Data 11, line 16) \\
\hline
\end{tabular}




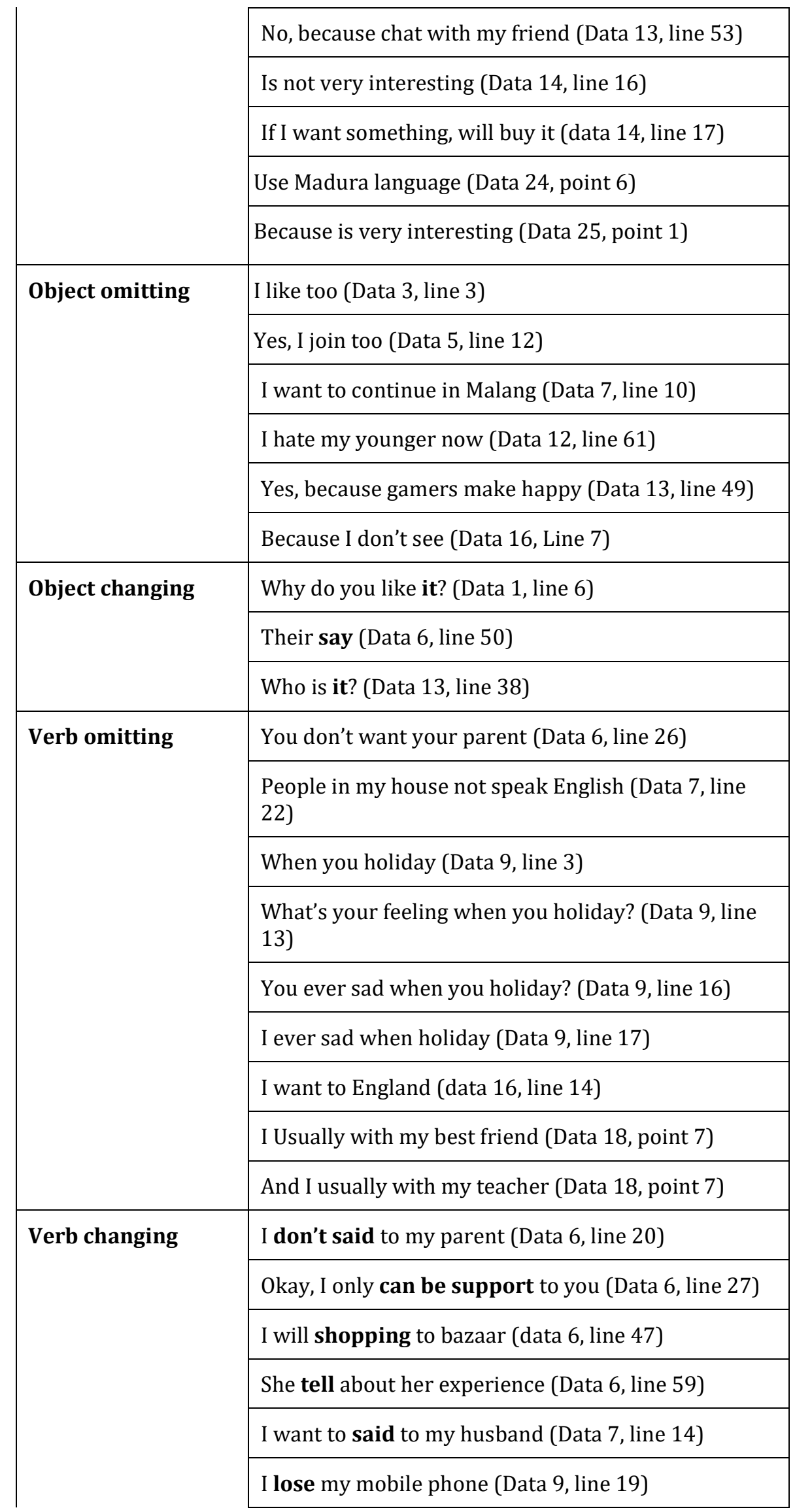


Imroatul Mufidah \& Eva Nikmatul Rabbianty, Madurese Dialect in the English ...

\begin{tabular}{|c|c|}
\hline & My phone is lose (Data 9, line 21) \\
\hline & When I drive motor cycle (Data 9, line 22) \\
\hline & From Waru go to Tamberu (Data 9, line 26) \\
\hline & My phone is lose (Data 9, line 26) \\
\hline & $\begin{array}{l}\text { When I given homework by my teacher (Data } 9 \text {, line } \\
\text { 34) }\end{array}$ \\
\hline & I am one brother ( Data 8, line 10) \\
\hline & Do you want married? (Data 11, line 12) \\
\hline & I cry (data 12 , line 38 ) \\
\hline \multirow{20}{*}{$\begin{array}{l}\text { Auxiliary verb } \\
\text { omitting }\end{array}$} & English language very important (Data 1, line 5) \\
\hline & I only at my house (Data 3 , line 5 ) \\
\hline & I from Potoan Laok village (Data 4, line 10) \\
\hline & What your feeling about Tamara? (Data 6, line 7) \\
\hline & You understand? (Data 6, line 33) \\
\hline & You understand? (Data 6, line 41) \\
\hline & You know? (Data 6, line 63) \\
\hline & My parent in Malaysia (Data 8, line 15) \\
\hline & $\begin{array}{l}\text { My mom teacher in Elementary school (Data 8, line } \\
\text { 18) }\end{array}$ \\
\hline & $\begin{array}{l}\text { What do you feel if you with your parent? (Data } 8 \text {, } \\
\text { line 20) }\end{array}$ \\
\hline & I very happy (Data 8 , line 21 ) \\
\hline & What your motivator? (Data 8, line 32) \\
\hline & You ever sad when you holiday? (Data 9, line 16) \\
\hline & I ever sad when holiday (Data9, line 17) \\
\hline & I think Bata-Bata very good (Data 10 , line 21 ) \\
\hline & I think Bata-Bata very interesting (Data 10 , line 22 ) \\
\hline & $\begin{array}{l}\text { What your opinion about Bata-Bata? (Data 10, Line } \\
\text { 23) }\end{array}$ \\
\hline & Bata-Bata famous in another city (Data 10 , line 25 ) \\
\hline & Understand? (Data 11, line 18) \\
\hline & You know it? (Data 12, line 27) \\
\hline
\end{tabular}




\begin{tabular}{|c|c|}
\hline & $\begin{array}{l}\text { My mother the same with your mother (Data } 12 \text {, line } \\
63 \text { ) }\end{array}$ \\
\hline & $\begin{array}{l}\text { Why you choose English Education in IAIN? (data 15, } \\
\text { line 9) }\end{array}$ \\
\hline & Her name miss Iim (data 16 , line 37 ) \\
\hline & Oh, you always travelling in Korea (Data 16, line 50) \\
\hline & $\begin{array}{l}\text { But Indonesia more beautiful than Korea (Data 16, } \\
\text { line 62) }\end{array}$ \\
\hline & I from Potoan Laok village (Data 9, point 2) \\
\hline & I from Batuampar (Data 11, point 2) \\
\hline & BBEC very interesting (Data 13 , point 1 ) \\
\hline Auxiliary verb & My hobby is reading and writing (Data 3 , line 8 ) \\
\hline & Are you like BBEC? (Data 4, line 6) \\
\hline & I am very sad (data 9 , line 26 ) \\
\hline & I am crying here (Data 12 , line 38 ) \\
\hline & My father don't dear me (Data 12 , line 53) \\
\hline & I don't happy (Data 12 , line 59) \\
\hline & Do you ever travelling in Korea? (data 16, line 51) \\
\hline Preposition & But me (data 6, line 9) \\
\hline & $\begin{array}{l}\text { What is name your younger brother? (Data 12, line } \\
\text { 21) }\end{array}$ \\
\hline & with member BBEC (Data 7, point 7) \\
\hline & I like listen people speak English (Data 20, point 1) \\
\hline & Member BBEC (Data 22, point 7) \\
\hline Preposition & I don't join to Tamara (Data 6, line 11 ) \\
\hline & If I don't join to Tamara (Data 6, line 13 ) \\
\hline & If I join to BBEC (Data 6 , line 20 ) \\
\hline & But, if I join to Tamara (Data 6 , line 23 ) \\
\hline & $\begin{array}{l}\text { I ever say to my parent to my ambition (Data } 7 \text {, line } \\
\text { 5) }\end{array}$ \\
\hline & to continue in other school (Data 18, point 2) \\
\hline
\end{tabular}


Imroatul Mufidah \& Eva Nikmatul Rabbianty, Madurese Dialect in the English ...

\begin{tabular}{|c|c|}
\hline & $\begin{array}{l}\text { I Usually with my best friend In member BBEC (Data } \\
\text { 18, point 9) }\end{array}$ \\
\hline & Why I join at bbec (Data 22 , point 1 ) \\
\hline \multirow{10}{*}{$\begin{array}{l}\text { Third person } \\
\text { singular omitting }\end{array}$} & English make me happy (Data 1, line 7) \\
\hline & My teacher always give me support (Data 1, line 13) \\
\hline & $\begin{array}{l}\text { He always support me to learn English (Data 5, line } \\
\text { 7) }\end{array}$ \\
\hline & $\begin{array}{l}\text { The translator translate from people (Data 6, line } \\
54 \text { ) }\end{array}$ \\
\hline & Someone come to my school (Data 7, line 21) \\
\hline & Someone who come to your school (data 7, line 24) \\
\hline & Because cook make me happy (Data 13 , line 8 ) \\
\hline & Because make up make me dizzy (Data 13, line 16) \\
\hline & $\begin{array}{l}\text { Because swim make me happy and make me enjoy } \\
\text { (Data 13, line } 42 \text { ) }\end{array}$ \\
\hline & Make me interested to join BBEC (Data 23, point 1 ) \\
\hline \multirow[t]{3}{*}{ Article omitting } & Tamara is interesting event (Data 6 , line 22) \\
\hline & I have younger brother also (Data 13 , line 3 ) \\
\hline & I have brother (Data 14, line 9) \\
\hline \multirow[t]{2}{*}{$\begin{array}{l}\text { Passive form } \\
\text { changing }\end{array}$} & $\begin{array}{l}\text { English language need in all of place (Data 18, point } \\
\text { 1) }\end{array}$ \\
\hline & $\begin{array}{l}\text { English also need to continue in other school or } \\
\text { university (Data 18, point 1) }\end{array}$ \\
\hline \multirow[t]{3}{*}{$\begin{array}{l}\text { Conjunction } \\
\text { changing }\end{array}$} & $\begin{array}{l}\text { I want to said to my husband because I want to be a } \\
\text { teacher (Data 7, line 14) }\end{array}$ \\
\hline & The same with me (Data 10, line 14) \\
\hline & $\begin{array}{l}\text { Do you have friend and your friend have step mother } \\
\text { or step father? (data 13, line 36) }\end{array}$ \\
\hline \multirow[t]{5}{*}{ Reverse } & Why you don't join Tamara? (data 6, line 17) \\
\hline & In Pekan ngaji will there is bazaar (Data 6, line 44) \\
\hline & You lazy to study don't (Data 7, line 7) \\
\hline & In my house English (Data 7, line 18) \\
\hline & To take course English (Data 7, line 23) \\
\hline
\end{tabular}




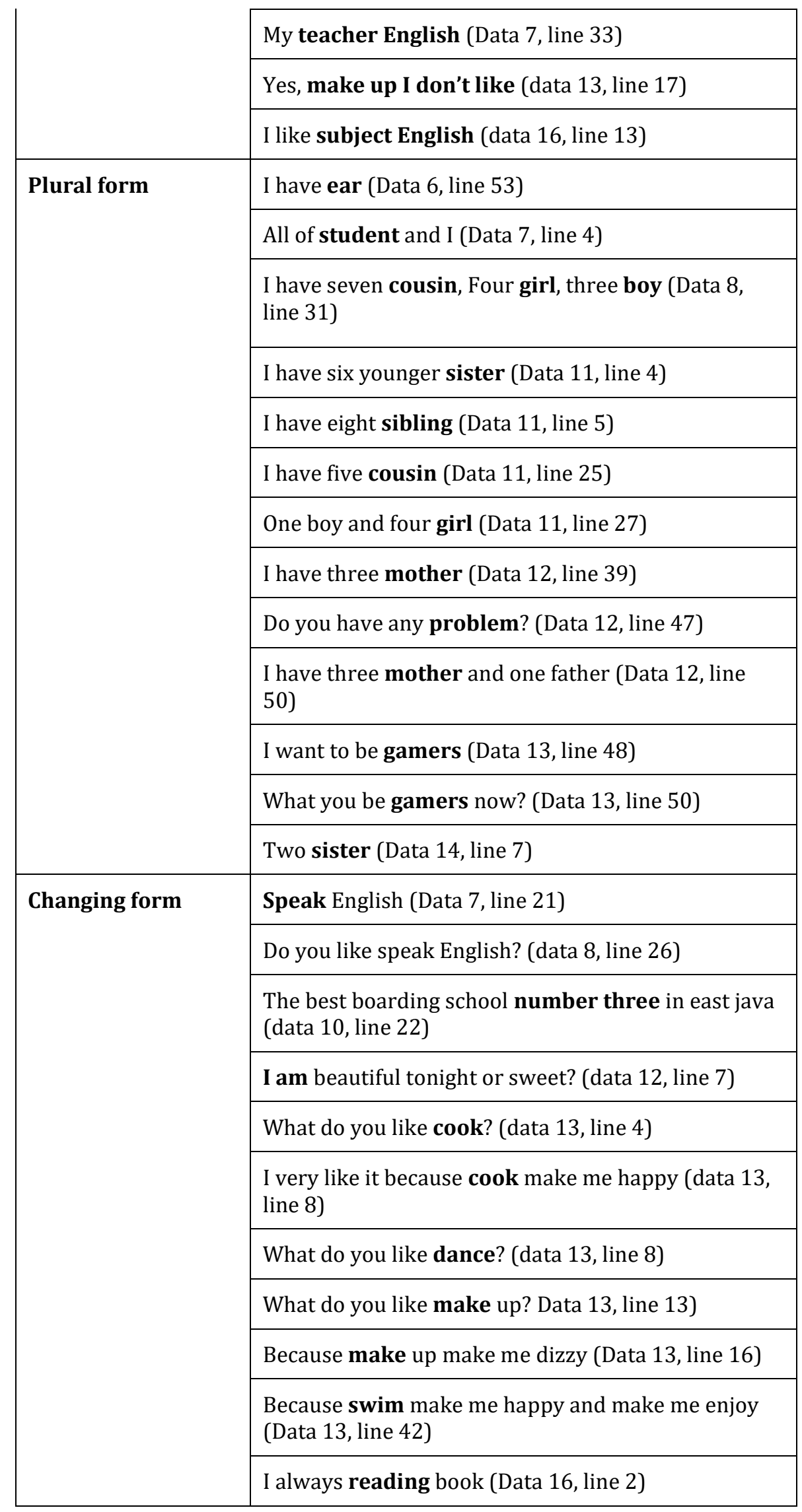


Imroatul Mufidah \& Eva Nikmatul Rabbianty, Madurese Dialect in the English ...

\begin{tabular}{|c|c|}
\hline \multirow[t]{17}{*}{ Adding } & My ambition is to be teacher \\
\hline & After I take course in my take course (Data 7 , line 20) \\
\hline & Because my relatives is help me (Data 8 , line 11 ) \\
\hline & Makes me to sad (Data 8, line 21) \\
\hline & I am confuse (Data 9, line 4) \\
\hline & I study here the longer than you (Data 10, line 19) \\
\hline & What do you like cook? (data 14, line 4) \\
\hline & What do you like dance? (Data 13 , line 8 ) \\
\hline & What do you like make up? (data 13 , line 13 ) \\
\hline & What do you like Banana? (Data 13, line 26) \\
\hline & What do you have friend (Data 13 , line 30 ) \\
\hline & What do you have friend (Data 13 , line 36 ) \\
\hline & What do you like swimming? (Data 13, line 41) \\
\hline & What do you like game? (Data 13 , line 47 ) \\
\hline & What do you have best friends? (data 13 , line 58 ) \\
\hline & Because Boruto is support me (Data 17 , line 36 ) \\
\hline & He is very support me (Data 17 , line 36 ) \\
\hline \multirow[t]{8}{*}{ Ambiguous form } & Yes, face to face but listening at Pare (Data 2, line 8) \\
\hline & $\begin{array}{l}\text { In my house English, all of people in my house is not } \\
\text { important said people in my house (data 7, line 19) }\end{array}$ \\
\hline & What do you support? (Data 8, line 32) \\
\hline & Do you help grandmother? (Data 8, line 40) \\
\hline & $\begin{array}{l}\text { I don't know with grandfather and grandmother } \\
\text { (Data 11, line 29) }\end{array}$ \\
\hline & Why I say it, because you don't (Data 12, line 10) \\
\hline & Because dance not happy (Data 13, line 11) \\
\hline & What do you like favorite drink? (Data 13 , line 23 ) \\
\hline \multirow[t]{4}{*}{ Voice changing } & She is very smart (Data 4 , line 12 ) \\
\hline & He is very clever (Data 5 , line 3 ) \\
\hline & I think Tamara is international event (Data 6, line 9) \\
\hline & $\begin{array}{l}\text { I think my parent will try to seek money (Data 6, line } \\
\text { 13) }\end{array}$ \\
\hline
\end{tabular}




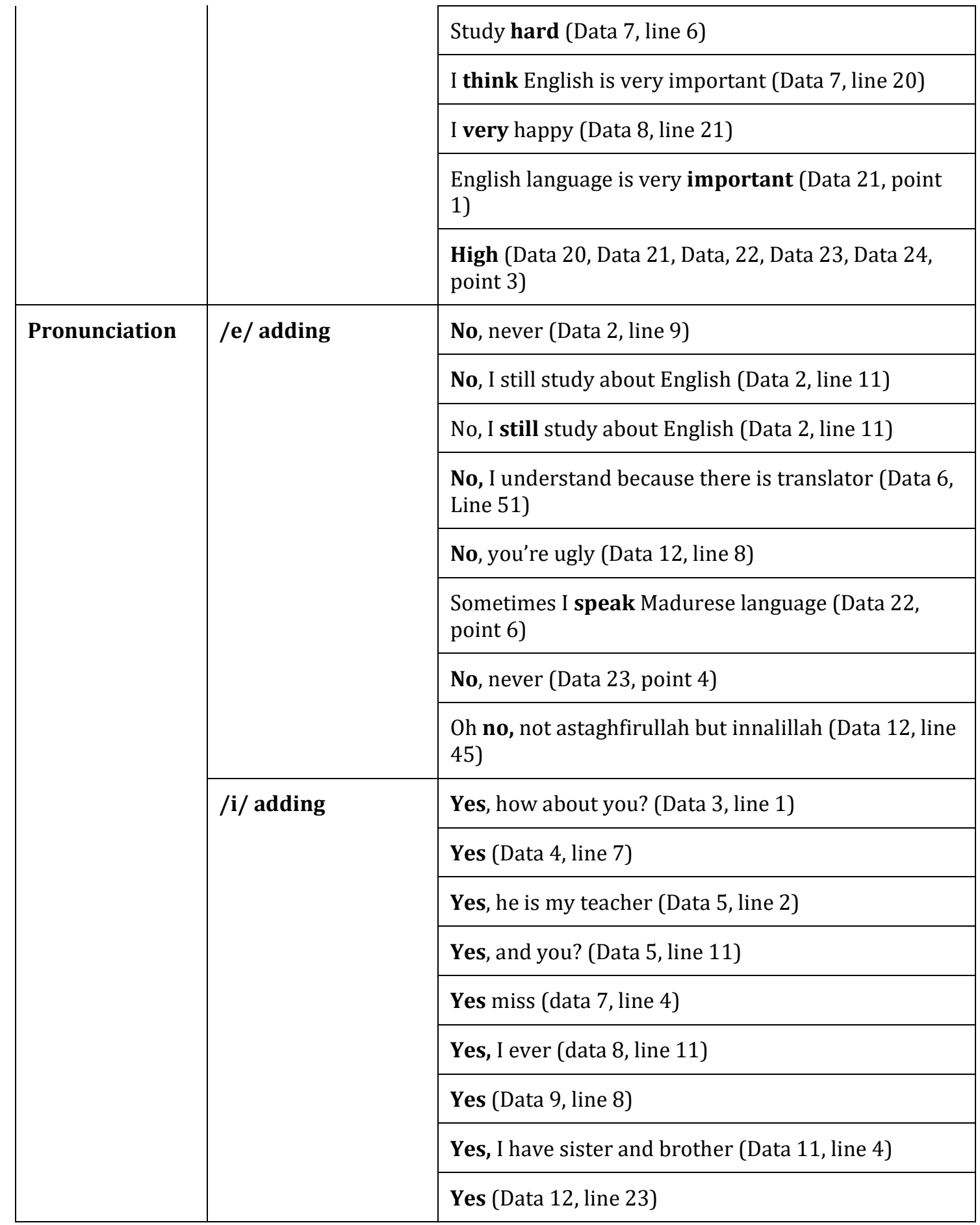

The phenomenon of Madurese dialect in talking English by the members of BBEC is essentially influenced by education factor which they are less of English knowledge. There are three causes of their dialect in using English. The first is students' lack of vocabulary. And second, they influenced their English by Madurese language. The last, they never listen to native speakers. 
Imroatul Mufidah \& Eva Nikmatul Rabbianty, Madurese Dialect in the English ...

\section{Lack of Vocabulary}

Based on the answer from some students, it shows that the members of BBEC lack vocabulary. We can know from the answer of one of the students that she is only graduated from elementary school, which learns English only once every week. Then, for the other responses, she said she only has 300 vocabulary mastery for the range 1001000. Besides that, four of them said that mastering 400 English vocabulary. Then, two of them have about 500 English vocabulary. In the last one, they are three students that have 600 vocabulary mastery. We can find out this phenomenon from the example of a sentence made by the members of BBEC "you can see alone" from this sentence shows that the vocabulary is used improperly because of a lack of English vocabulary.

\section{Influenced by Madurese Language}

Madurese language as their mother tongue has an impact on their English as their foreign language. It happens because their habits are using Madurese language. The fact that language is universally changeable and changes in different ways at different times and places is, of course, the basic fact of historical linguistics (Bright, 2007).We can show it by the answers of the members of BBEC in the interview session. No one uses English as their daily communication. All of them use Madurese language or sometimes Indonesian language as their daily conversation.

They only speak English in the teaching-learning program. Even BBEC is an English short course, sometimes they still use Madurese language or mix the language. It is influenced by how they dialect in the English conversation. It can be from their grammatical pattern, choosing the vocabulary, or even pronouncing some words. We can know how their Madurese language affects their English by the example, "English language very important" or "I only at my house" both of those sentences are missing auxiliary verbs. It happens because they tend to bring their mother tongue, which is Madurese language when they talk using English. After all, there is no auxiliary verb needed in Madurese language.

\section{Never Listen to Native Speaker}

The third cause is about native English speakers. Nine of ten students never listen to the native speaker directly, and two of nine students only listen to the native speaker on the television. At the same time, the other students or seven members of BBEC said that they never listen to the native speaker. Listening to an English native speaker is essential if someone wants to learn English because learners can imitate the right form of the language. Learning English to non-native speakers sometimes makes a mistake or teaches the wrong language form; it can be from vocabulary, grammatical pattern, or even pronunciation. 


\section{Discussion}

The data analyzed in the previous section shows that Madurese dialect phenomenon occurs when the Bata-Bata English Centre (BBEC) members talk using English.

\section{Patterns of Madurese Dialect by the members of BBEC}

The phenomenon of Madurese dialect by the members of BBEC is in the form of vocabulary, grammatical pattern, and pronunciation. It is in harmony with the form of dialect from Janet Holmes (Holmes, 2013). Grammatical patterns become the most dialect used by the members of BBEC, but the forms of pronunciation and vocabulary also happen. Like the previous study held by (Azror, 2016), grammatical patterns became the most dialect used.

In the form of vocabulary, there are some incorrect of choosing vocabulary. The previous studies conclude that students faced the problem in vocabulary learning very seriously. The students also found difficulties in selecting the appropriate meaning of the words and were still confused using the word based on the context (Rohmatillah, 2017). The members of BBEC choose the vocabulary based on their understanding. They think that the listener will understand what they talk about, so they ignore whether their words are proper and correct or not. They just focus on understanding each other. It again concludes because they lack English knowledge and lack vocabulary. So, they tend to ignore the rule of standard English and choose the vocabulary to depend on their understanding.

In the grammatical pattern, the researcher found out 18 forms of incorrect grammar utter by the members of BBEC. The first is subject omitting, and they do not mention the subject when they talk because they think the listener understands whom they talk about. The second is object omitting. The object has a crucial role in the sentence, but they do not mention the object because they think the speaker understands what they want to say, although they omit the object for the transitive verb. The third is object changing. Most object changing happens when they cannot differ the pronoun for plural and singular. The fourth is verb omitting; the members of BBEC sometimes omit the verb because they think that the listener understands the topic and will simplify their utterance by omitting the verb. The fifth is verb changing. This one happens when the speakers change the verb. Most of them use verb 1 in the past tense. The sixth is auxiliary verb omitting, it happens because in Madura language, they do not need an auxiliary verb, so when they talk using English, they still use the pattern of Madurese language grammar, they tend to bring their dialect of Madurese language and ignore the rule of English language. The seventh is auxiliary verb changing. Change the auxiliary because the speaker does not differ the singular or plural noun that they talk about. The eighth is preposition omitting. It occurs to some of the members of BBEC. They omit the preposition, whereas preposition is also important in the sentence. 
Imroatul Mufidah \& Eva Nikmatul Rabbianty, Madurese Dialect in the English ...

Sometimes, they also change the preposition as, like the tenth incorrect grammar, it is preposition changing. While the eleventh feature in incorrect grammar third-person singular omitting is influenced by Madurese language because they do not need to put prefix after the verb if the subject is third-person singular, which means there are no classification of verb depends on the subject. Then, the next is the article omitting. Omit the article is done by some members of BBEC. They think that the article is not important because the listener sill understand the context of what they talk about. The thirteenth is passive form changing. Although most of their utterance use the active form, sometimes they use the passive form. They still use the pattern of active form. The fourteenth is conjunction changing. In this case, the speakers do not realize that they use improper words because they lack vocabulary and cannot differentiate the conjunction function itself. The next is reverse. This point shows that Madurese language influences their English because, in this case, the members of BBEC translate their utterance word by word. The plural form is the next point of the grammatical pattern feature. Sometimes, they cannot put the sign of plural form, which is s/es. Again, it happens because they try to tend to bring the dialect of Madurese language. Next is changing form; this case occurs in some dialogues. Adding also happens in the conversation of the members of BBEC. They put a word or some word which is not needed. The last is ambiguous form, which means the utterance is incorrect so that the speaker can misunderstand.

In the form of phonology feature, there are three patterns find out by the researcher on the English conversation by the member of BBEC. The first is voice changing. It happens in some words made by them. For example, when they say "very," they do not pronounce using voiced sound, but voiceless, becomes "feri." The other example is when they pronounce "high," they pronounce that word is not by the standard pronunciation, but they follow the letter of the word. The second and the third are in harmony with Azror's study (2016). There are /e/ adding and /i/ adding. The members of BBEC often add the sound /e/ in front of or in the middle of the world. It shows in some words, "no" which the standard pronunciation /nəv/ "becomes /enəv/, "still", /stıl/ becomes /strl/, and "speak", /spi:k/ becomes /sepi.k/. The next is /i/ adding. This pattern only happens in one word "yes" but mostly utter by the members of Bata-Bata English Centre (BBEC). They put the /i/ sound in front of the word, making it unsuitable for the standard pronunciation.

\section{Factors Affecting Madurese Dialect in The English Conversation}

BBEC members are English learners who live in Madura, and Madurese language is their mother tongue. There are some factors that affect how their dialect in their English conversation. The researcher found out three factors that influenced their dialect in the English conversation. 


\section{Lack of Vocabulary}

Lack of vocabulary makes it difficult to talk in English because they find it difficult to find the appropriate English vocabulary. It affects their English conversation where sometimes they choose inappropriate vocabulary.

2. Influenced by Madurese Language

As the researcher has mentioned above, the members of BBEC is people of Madura. They use Madurese language as their daily communication. It is in harmony with the studies that conclude that English of Madurese studentsis influenced by Madurese L1 background of the students (Sa'adiyah et al., 2017). Besides that, Madurese language is their mother tongue, while English is their foreign language. The form of Madurese language affects how they speak using English language; sometimes they brought the dialect of Madurese language to their English conversation.

3. Never Listen to Native Speaker

The third factor is they never listen to native English speaker. Many teachers do not pay enough attention to the importance of Listening comprehension in their class (Gilakjani \& Sabouri, 2016). Listen to English native speaker becomes important to know the right form of English language. Most of the members of BBEC never listen to native English speakers, so they often speak using English incorrectly. It can be from their vocabulary, grammatical pattern, and pronunciation.

\section{CONCLUSION}

The research shows the patterns of Madurese dialect in the English conversation made by the members of BBEC and the factor affecting their dialect. There are some patterns of their dialect, classify by vocabulary, grammatical pattern, and pronunciation. From the vocabulary, there are four inappropriate vocabulary, which are little-little, advise, fine, and alone. Besides that, the grammatical pattern which used by the members of BBEC are invested in subject omitting, object omitting, auxiliary verb omitting, verb omitting, object changing passive form changing, preposition changing, preposition omitting, thirdperson singular omitting, subject and auxiliary verb omitting, auxiliary changing and ambiguous form. The last is pronunciation; here are three patterns of the phonological feature. First is voice changing, they often change the sound of the word, so it is different from the standard pronunciation. The second is /e/ adding, and the last is /i/ adding, when they often add /e/ and /i/ sound in front of or in the middle of the world.

Three factors affect how their dialect in the English conversation. The first is lack of vocabulary; it is caused they still lack English knowledge. It causes difficulties to find the appropriate vocabulary when they talk using English. The second is influenced by Madurese language. Madurese language is their first language used every day as daily communication, so they tend to bring the characterization of Madurese language in the English conversation. The last factor is never listening to native English speakers. 
Imroatul Mufidah \& Eva Nikmatul Rabbianty, Madurese Dialect in the English ...

\section{REFERENCES}

Azror, C. (2016). Englsh Speaking Dialect Used by Madurese Students of SMPN 1 Klampis in Bangkalan Madura. Thesis, Universtas Islam Negeri Sunan Ampel Surabaya.

Baker, W., Eddington, D., \& Nay, L. (2007). Dialect Identification: The Effect of Region of Origin and Amount of Experience. American Speech 84(1). https://doi.org/DOI: 10.1215/00031283-2009-004

Bright, W. (2007). Social Factor in Language Change. Blackwell Reference Online. https://doi.org/10.1111/b.9780631211938.1998.0007.x

Clopper, C. G., \& Smilijanic, R. (2011). Effects of Gender and Regional Dialect on Prosodic Patterns in American English. Journal of Phonetics, 39(2). 237-245. doi:10.1016/j.wocn.2011.02.006

Eastwood, J. (2008). Oxford Learner's Pocket Grammar. Oxford: Oxford University Press.

Fasold, R. W., \& Connor-Linton, J. (2006). An Introduction to Language and Linguistics. Cambridge: Cambridge University Press.

Fromkin, V., Rodman, R., \& Hyams, N. (2003). An Introduction to Language. Boston: Wadsworth Cengage Learning.

Gilakjani, A. P., \& Sabouri, N. (2016). The Significance of Listening Comprehension in English Language Teaching. Theory and Practice in Language Studies.6(8) https://doi.org/10.17507/tpls.0608.22

Hidayati, D., \& Thayyibah, N. (2020, Agustus). Madurese Dialect of Members of BBEC [Direct Interview].

Holmes, J. (2013). An Introduction to Sociolinguistics (4th ed.). London: Routledge.

Isiaka, A. L. (2021). Accommodation in L2 English: Measuring dialect Convergence in Nigerian Englishes. Language \& Communication, 79, 71-80. doi: 10.1016/j.langcom.2021.03.002

Jannedy, S., Poletto, R., \& Weldon, T. L. (Eds.). (1994). Language Files Materials for an Introduction to Language \& Linguistics (sixth). Ohio State University Press.

Mantiri, O. (2010). Factors Affecting Language Change (SSRN Scholarly Paper No. ID 2566128). Rochester, NY: Social Science Research Network. doi: $10.2139 /$ ssrn.2566128

Nordquist, R. (2019). The "Expanding Circle" of English-Speaking Countries. Retrieved September 24, 2021, from ThoughtCo website: https://www.thoughtco.com/expanding-circle-english-language-1690619.

R Umagandhi \& R Sindhuja. (2017). Socio-Linguistics and Language Variation. International Journal of Multidisciplinary Research and Development, 4(11), 107108.

Rohmatillah, R. (2014). A Study on Students' Difficulties In Learning Vocabulary. English Education: Jurnal Tadris Bahasa Inggris, 6(1), 75-93. doi: 10.24042/eejtbi.v6i1.520

Sa'adiyah, E. N., Rezti, D., \& Mufidah, L. (2017). The Influence of Madurese L1 Background on The Student's English Consonantal Sounds Production. INTERAKSI: Jurnal Kependidikan, 12(2), 129-133. 
Salano-Flores, G. (2006). Language, Dialect, and Register: Sociolinguistics and the estimation of Measurement Error in the Testing of English Language Learners. 108.

Shams, T. (2018). Language Variation. https://languageavenue.com/linguistics/sociolinguistics/languagevariation/item/language-variation

Siregar, S. (2017). The Influence of Dialect on The Student's Pronunciation in Speaking Ability. Pedagogy: Journal of English Language Teaching, 5(1), 27-36. doi: 10.32332/pedagogy.v5i1.766

Wardhaugh, R. (2006). An Introduction to Sociolinguistics (5th ed.). Boston: Blackwell Publishing.

Wolfram, W., \& Friday, W. C. (1997). The Role of Dialect Differences in Cross-cultural Communication: Proactive Dialect Awareness. Bulletin Suisse de Linguistique Appliquee, 65, 143-154. 